\title{
PHYSICAL-GEOGRAPHIC BASIS OF REGIONAL DEVELOPMENT OF GREAT PLAINS (NORTH AMERICA)
}

\author{
Ivana Penjišević', Nikola Milentijević', Bojana Jandžiković ${ }^{1}$ \\ Received: April 17, 2018 | Accepted: June 21, 2018
}

\begin{abstract}
The Great Plains region covers a third of the territory of the United States and only $3 \%$ of the total population lives in it. This disproportion between the size of the territory and the number of inhabitants in it is caused by specific natural conditions in the region. Typical prairie region which runs along the meridian is distinguished by its continuality and strong thermal contrasts. The southern parts of the Great Plains receive more rainfall due to the Gulf of Mexico, while the in the north, towards the Canadian prairie, the winters become colder and sharper. The "Hydrographic lifeblood" of the Great Plains is the Missouri River with the Mississippi River, which represents a very important navigation route of $19000 \mathrm{~km}$. Although the Great Plains are among the last regions in North America that have been used as vegetable surfaces, this hydrosystem serves for irrigation, which resolves the long-standing problem of drought. Thanks to the great spaciousness of high quality chernozem, this region was turned into a continuous breeding zone for hybrid grain varieties, which comprise $75 \%$ of US wheat exports. During the research, predominantly analytical and synthetic methods were used, while climatic elements and demographic characteristics were analyzed using the statistical method.
\end{abstract}

Keywords: Great Plains, physical and geographical features, regional development, climate

\section{INTRODUCTION}

The Great Plains region extends between the delta of the Makenzi River in the north and the Rio Grande River in the south. The eastern boundary is comprised of parts of the Canadian Shield, while the western boundary is determined by the massive Rocky Mountains (Figure 1). The region's surface is $2.900 .000 \mathrm{~km}^{2}$, which makes up one-third of the United States. The length of the region of the Great Plains is about $4,800 \mathrm{~km}$, and the width is $300-600 \mathrm{~km}$. The entire region features large plateaus, which extend at an average height

\footnotetext{
Department of Geography, Natural Sciences and Mathematics, University of Pristina, Kosovska Mitrovica, corresponding author e-mail: ivana.penjisevic@pr.ac.rs
} 
of 1,000-1,500 $\mathrm{m}$. They are lowered to to a height of $300 \mathrm{~m}$ on the eastern rim; while on the western rim they rise up to $1,800 \mathrm{~m}$ (Petrović, Ilić, 1979). In administrative terms, this vast prairie area extends across ten states of the United States (Montana, North Dakota, South Dakota, Wyoming, Nebraska, Kansas, Colorado, Oklahoma, Texas and New Mexico), the Canadian Midwest (Manitoba, Saskatchewan and Alberta) and parts of the Northwest Territories (https://www.britannica.com/place/Great-Plains).

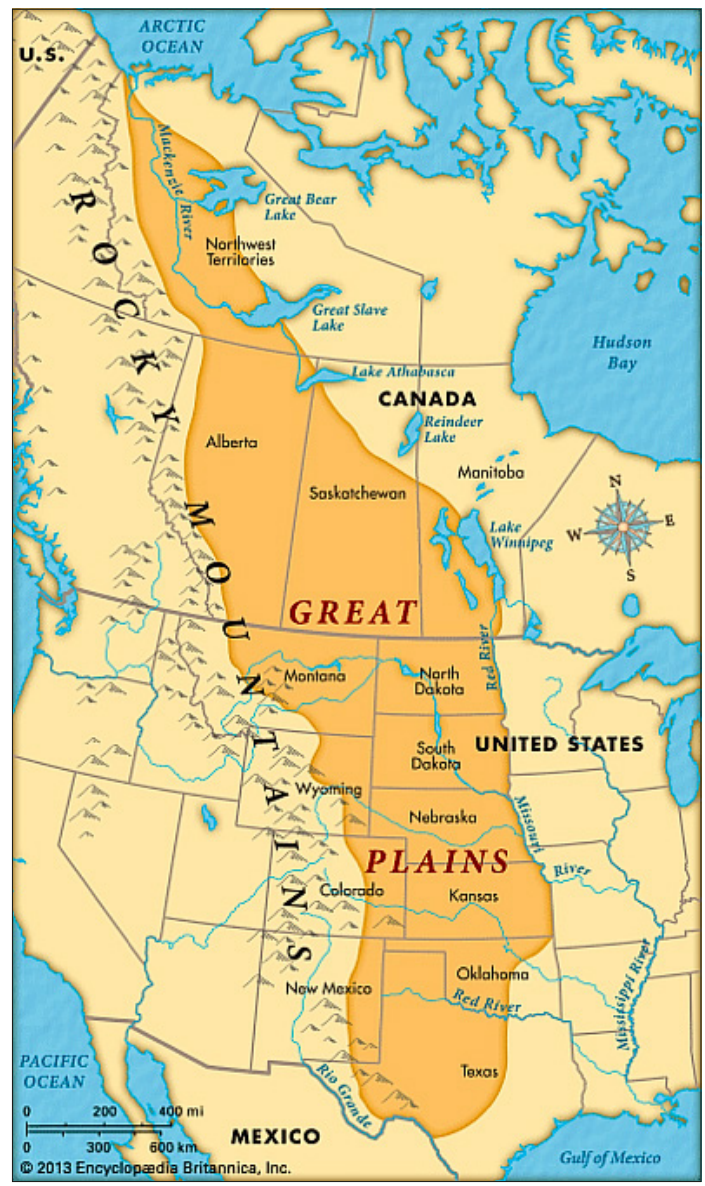

Figure 1. Geographic position of Great Plains

(Source: http://kids.britannica.com/kids/assembly/view/178836)

\section{PHYSICAL-GEOGRAPHIC FORMATION OF GREAT PLAINS}

The formation of the morphological appearance of the Great Plains is marked by frequent withdrawal and return of the sea during the Mesozoic. It is a lowland area, actually a flat plateau, from which the lonely mountainous areas rise. Climate of the Great Plains is marked by continentality in the central parts, by the influence of moist air from 
the Gulf of Mexico in the southern parts and polar air in the northern parts of the region. Water resources are represented by the Misuri-Misisipi system, with its tributaries. The land of the studied region belongs to chernozem, zonal type of land, it is a high quality land. Anthropogenic action, a former prairie with huge bison herds, has been turned into the most important agricultural region of North America.

\section{Geological past in the function of development of the mining region}

The basis of the geological structure of the Great Plains consists of the oldest, Palaeozoic structures, of which the most powerful and best known are the upper Carbon. Coal deposits in Pennsylvania, the periphery of Apalaca and in the west of the Mississippi area are connected to these sediments. The long-term effects of erosion processes partially stripped the older, Paleozoic walls and created isolated elevations and hill chains, such as Ozark, Kuchita and Vichita.

During the Triassic and Jurassic in the Great Plains area there was a sea. At the end of the Jurrasic, it retreated, and, in Cretaceous, it flooded the area again to the mouth of Ohio and the rim of the Canadian Shield (Figure 2). On the western rim of the existing sea basin, the rise of the Rocky Mountains began. The Great Plains belt follows the Rocky Mountains at a width of 300-600 km. The river's accumulation was much stronger than in the lowland, and the tertiary rise of the mountain chain of the Rocky Mountains led to the retreat of this peripheral plain. They rise above the Great Plains at a height of 1,000-1,500 m, and on the very rim of the mountains up to 1,800 m. From the Rocky Mountains the rivers later brought large quantities of eroded material and accu-

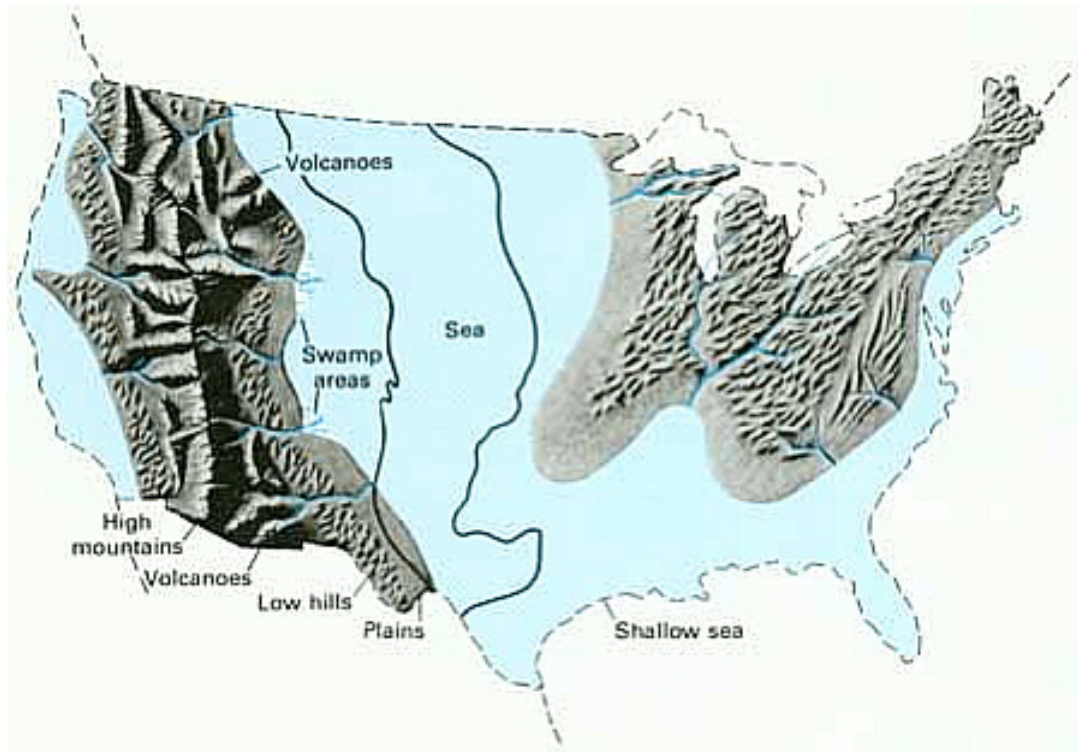

Figure 2. The paleogeographic appearance of the United States during the late Cretaceous (65 to 80 million years), when the largest part of the High Plains was below the sea level (Source:https://www.nps.gov/parkhistory/online_books/geology/publications/bul/1493/images/fig6.jpg) 
mulated that material in the coastal parts of the sea. In this way, younger deposits were deposited on the seabed, through the Paleozoic surface. Due to the complex paleogeographical development, accompanied by frequent transgressions and regressions, due to the the formation of isolated basins and the erosion activity, the formations of Cretaceous, tertiary, river, lake and marine sediments are intertwined (Petrović, Ilić, 1979).

Long-term existence of the sea has caused that today in several locations in the Great Plains there are rich deposits of lignite, phosphorus and phosphate. Four countries ( $\mathrm{Wy}$ oming, North Dakota, Montana and Colorado) have large coal reserves, but all of them except Wyoming have a small share in total coal production in the United States. When it comes to the production of oil and natural gas in the Great Plains, Texas is emerging as the leading US state. Production in 1981 amounted to about a million barrels per year, to halve in 2005 to around 400,000 barrels. Data from 2016 indicate a recovery of US oil production, which amounts to 1.3 million barrels per year (https://pubs.usgs.gov/ bul/1493/report.pdf)

\section{Morphological features of the Great Plains}

In the morphological sense, the Great Plains represent a high plateau covered with grassy vegetation, which developed under conditions of semi-arid climates. The altitude varies from 1,800 $\mathrm{m}$ on the western boundary (Rocky Mountains), up to 1,500 $\mathrm{m}$ on the eastern boundary (Apalaca Mountains). In the north, within the Canadian provinces, altitudes are just above the sea level. Some areas, in western Texas and eastern New Mexico, are very plain. The lowland area along the coast of the Gulf of Mexico is the belt of accumulation of recent deposits, so numerous sediment walls and lagoon-type bays are formed (Vasović, 1971).

Black Hills rise above the surrounding plains and stand out with their forestation. Certainly the most impressive feature is a large, flat plateau - Great Plains, from which the formations due tu erosion in the form of cliffs arise. In the far north of the region in contact with Missouri Plateau, a continental glacier stands out. At the end between the Piedmont Plateau (Piedmont) in the north and the Pecos Valley in the south, there are numerous post-volcanic phenomena and fossil volcanic forms of relief (https://pubs. usgs.gov/bul/1493/report.pdf). The diverse morphological forms of the Great Plains are the consequence of the complex paleogeography of the region.

\section{Climatic characteristics as the limiting factor of demographic development}

The Great Plains region is distinguished by the continental climate, which belongs to the $C f a$ and $C f b$ climate. Cold winters and warm summers are prevalent, with low precipitation and humidity, high intensity winds and frequent and sudden changes in temperature. The main source of moisture is the Gulf of Mexico, but the amount of moisture is very variable. Rain is more frequent in the summer than in winter, except for the northwestern parts of the region. The climatic features of the Great Plains were analyzed based on the available data from GMS Wichita, located in the southern part of the region $\left(\varphi=37^{\circ} 41^{\prime} \mathrm{N}, \lambda=97^{\circ} 20^{\prime} \mathrm{W}, \mathrm{Hs}=403 \mathrm{~m}\right)$. 
Air temperature. Analyzing the data with GMS Wichita (Table 1), we notice the existence of one maximum air temperature (in July) and a minimum temperature (in January). There is a sudden temperature rise, especially at the transition from winter to spring, which is of importance in the phenological sense. The amplitude of the temperature is significant $\left(28.1^{\circ} \mathrm{C}\right)$, which places this area in the category of extremely continental climate. The significant annual fluctuations in temperature are explained by thermal conditions in the summer and winter half of the year. In the summer, tropical air masses are formed over the warm North American land, while in the winter an anticicon is formed, which prolongs the cold weather (Milosavljević, 1990).

Table 1. Annual flow of air temperature at GMS Wichita (1981-2010)

\begin{tabular}{|c|c|c|c|c|c|c|c|c|c|c|c|c|}
\hline I & II & III & IV & V & VI & VII & VIII & IX & X & XI & XII & Year \\
\hline$-0,9$ & 2,1 & 6,9 & 13,6 & 18,9 & 24,0 & 27,2 & 26,2 & 21,3 & 15,0 & 7,0 & 1,3 & 13,6 \\
\hline
\end{tabular}

(Source: https://en.climate-data.org/location/1554/)

By comparing the temperature conditions of the Wichita meteorological station, located in the central part of the American prairie with the Canadian province of Saskatchewan, there are some differences regarding the increase in latitude. For comparison, in the Canadian prairie the winters are longer and colder, so January temperatures are lowered to $-50{ }^{\circ} \mathrm{C}$. The reason for this is the cold air which, due to the lack of barriers, penetrates further into the southern parts of North America. The years are warm, so July temperatures go up to $41^{\circ} \mathrm{C}$. There is a strong fluctuation of temperature in the winter and summer half of the year (https://www.britannica.com/place/Saskatchewan).

Winds. Winds from the south and southeast are warm and humid and they bring $70-80 \%$ of the precipitation to the southern and central parts of the region. Apart from regular southern winds of normal strength, in places where warm and cold currents clash, cyclone depression develops. There are destructive, swirling tornado winds (Tornado), moving at a speed of 400-500 km/h. Cyclones bring a cold northern wind (Norther), it is usually accompanied by snow blizzards, which cause major damage to traffic. Behind the cyclone, an anti-cyclone, which penetrates the Gulf of Mexico, usually settles for a longer time, bringing clear, calm and very cold weather (Petrović, Ilić, 1979). A characteristic winter phenomenon in the western part of the Great Plains is chinook. It is a warm and dry wind of the foehn character that blows along the eastern slope of the Rocky Mountains. It can raise a temperature of $17-22^{\circ} \mathrm{C}$ in a very short interval (https:// www.britannica.com/place/Great-Plains). It makes the winter mild, and sometimes allows livestock grazing throughout the winter (Petrović, Ilić, 1979).

Air humidity. Relative air humidity recorded at MS Wichita shows low values in summer (59\% - July), and moderate values in winter months (72\% - December).

Cloudiness. The highest cloudiness level recorded at MS Wichita is in winter (February - 60\%), while the lowest one is in summer (July - 30\%). The average annual cloudiness is small, accounting for $40 \%$ (https://weatherspark.com/y/8281/Average-Weatherin-Wichita-Kansas-United-States-Year-Round). 
Solar irradiance (Insolation). The duration of the sun's shine is greatest in the summer months (July - 342 hours), and the smallest in winter (December - 169 hours). The average annual insolation of MS Wichita is 2,900 hours of sunshine (https://en.wikipedia. org/wiki/Wichita, Kansas\#cite_note-67 ).

Precipitation. The pulvometric regime shows two maxima and a minimum of precipitation (Table 2). The maximum precipitation is in June $(115 \mathrm{~mm})$, while the second maximum in November $(39 \mathrm{~mm})$ is less pronounced. The transition seasons are also moist, which is of importance for the development and growth of grassland vegetation. On the other hand, the minimum precipitation is in January $(19 \mathrm{~mm})$, and February $(25 \mathrm{~mm})$ and December $(29 \mathrm{~mm})$ are dry as well. The total annual rainfall is $790 \mathrm{~mm}$. Precipitation rises towards the east, and is associated with the penetration of moist air from the Atlantic Ocean. The increase in rainfall in the northern part of the region goes up to $750 \mathrm{~mm}$, and in the south up to 1,500 mm (Milosavljević, 1990). For example, the Canadian Saskatchewan Province receives up to $510 \mathrm{~mm}$ precipitation (https://www.britannica.com/place/ Saskatchewan). In summer, precipitation usually occurs in the form of short-term showers and in the winter in the form of snowflakes. The whole region suffers from long-lasting summer drought, which is detrimental to agriculture (Petrović, Ilić, 1979).

Table 2. Annual rainfall in GMS Wichita (1981-2010)

\begin{tabular}{|c|c|c|c|c|c|c|c|c|c|c|c|c|}
\hline I & II & III & IV & V & VI & VII & VIII & IX & X & XI & XII & Year \\
\hline 19 & 25 & 54 & 68 & 107 & 115 & 93 & 82 & 92 & 67 & 39 & 29 & 790 \\
\hline
\end{tabular}

(Source: https://en.climate-data.org/location/1554/)

Based on the Copenhagen Climatic Classification, a part of the Great Plains region of the United States belongs to the $C f a$ climate - temperate-warm, humid climate with hot air (the mean value of the warmest month $>22^{\circ} \mathrm{C}$ ). On the other hand, Canadian provinces belong to the $C f b$ climate - a humid, boreal climate with a warm summer (the average temperature of the hottest month is equal to or lower than $\left.-3^{\circ} \mathrm{C}\right)$. The climate is characterized by abundant precipitation $(750-1500 \mathrm{~mm})$ and their favorable distribution throughout the year. The maritime air which has its origin in the Gulf of Mexico and which brings rainfall, with high daily air temperatures, presents the reason why the climate of these parts is hard to bear during summer. The climate is favorable for the development of the plant world, and grass formations appear in the form of prerae (Šegota, Filipčić, 1996).

Climatic characteristics are the limiting factor of demographic development, because only $3 \%$ of the total population lives on a third of the territory of the United States. Demographic trends in the region High Plains deviate from the usual national patterns. This disproportion between the area of the region and the number of inhabitants living on it is caused by natural conditions, primarily an unfavorable climate. The density of population in the Great Plains is only 7 flats $/ \mathrm{km}^{2}$, which is about six times less than the US average (43 flats $/ \mathrm{km}^{2}$ ). The basic demographic characteristics of the region are the increase in the number of inhabitants (1950-2007), a high percent of the old population ( $>65$ years and older) and marked emigration. Population of the region shows stable growth over the past 
decades (1950-2007). Thus, in 1950, there were nearly 4.9 million inhabitants, and in 2007 estimates indicate that the number doubled - 9.9 million (Table 3). The period of the highest growth in the region was achieved in the interim period, 1990-2000 (1.4 million apartments). The lowest growth rates were from 1960 to 1970 (249 thousand).

Table 3. Movement of the population of the High Plain (1950-2007)1

\begin{tabular}{|c|c|c|c|}
\hline Census period & Population & Increase in number (in thousands) & Incerase (in \%) \\
\hline 1950. & 4.891 .888 & $/$ & $/$ \\
\hline 1960. & 5.747 .147 & 855.259 & 14,9 \\
\hline 1970. & 5.996 .837 & 249.690 & 4,2 \\
\hline 1980. & 6.996 .232 & 999.395 & 14,3 \\
\hline 1990. & 7.579 .566 & 583.334 & 7,7 \\
\hline 2000. & 8.962 .343 & 1.382 .777 & 15,4 \\
\hline 2007. & 9.897 .182 & 934.839 & 9,4 \\
\hline
\end{tabular}

(Source: Population Dynamics of the Great Plains: 1950 to 2007, U.S. Census Bureau, July 2009, https://www. census.gov/prod/2009pubs/p25-1137.pdf)

European immigrants have played a significant role in the settlement of the High Plain. By 1910, immigrant families accounted for almost half the population of six states in the region (Montana, North Dakota, South Dakota, Wyoming, Nebraska and Kansas). Today, in the second decade of the $21^{\text {st }}$ century, the demographic picture of the Great Plains is endangered by the emigration components of population migration. During 2006-2007, the region had 97,800 migrants. The age structure of the population of the United States changed from 1950 to 2007, with the average age of the population shifting from 30.2 to 36.6 years. A similar trend was observed in the population of the region, where the average age increased by 6.4 years (from 28.5 to 34.9 years). This indicates the emergence of aging population. Also, the share of the old population ( $>65$ years and older) has increased. However, in terms of settlements, the metropolitan areas of the region show a higher share of the young population, while rural settlements show markedly demographic aging (https://www.census.gov/prod/2009pubs/p25-1137. pdf). The largest cities of American part of the Great Plains are Denver (2 million inhabitants), San Antonio (1,5 million inhabitants) and Oklahoma City (1 million inhabitants ) and Kalgari (990,000 inhabitants), Edmonton (967,000 inhabitants) and Vinipeg (685,000 inhabitants) in Canadian part.

\section{Hydrographic features of the Great Plains}

The Great Plains in the United States is drained by the Missouri River, which, with its mouth Mississippi (6,800 km), belongs to the Gulf of Mexico. From the Rocky Mountains, the following Missouri's tributaries appear: Jelouston, Plat and Kansas. Mississippi's tributaries that come from Rocky Mountains are Arkansas and Red River. From the

1 Statistical data relating to 2007 are the estimates of the National Population Bureau. 
southern part of the Rocky Mountains, Rio Grande drains the water to the bay (Petrović, Ilić, 1979). The Red River, in the north, forms the boundary between North Dakota and Minnesota. The prairie of Great Plains in the area of Canada is drained by the Saskatchewan River with its tributaries.

\section{Land cover as a factor in the development of agriculture in the Great Plains}

The modern pedological coverage of North America is conditioned by the interaction of several factors: the great extension of the continent in the meridian direction, the existence of a high chain of fold mountains along the west coast that form a climatic barrier and quaternary glaciation (glacial, fluvio-glacial, preglacial and loess deposits). The belt width temperature is best reflected on the land cover of the eastern and central plains of the continent (Lješević, 2010). Through the central part of the continent, at a width of 500-1,000 km, the belt of prairie and steppe stretches, the central part of which is covered with a very fertile prairie chernozem. Towards the east, in the grassforest zone, the soil goes into degraded chernozem and podzols, significantly less fertile (Petrović, Ilić, 1979).

Prior to the colonization of European immigrants, the North American prairie was the habitat of autochthonous mammals. Due to the settlement of the Great Plains and the creation of traffic connections with neighboring areas, mass extermination of the bison occurred (Djurić, Petrović, 1965). Today's cattle breeding in the region has been developed on large cattle farms (ranchers), where a species of American cattle with lots of meat is cultivated.

Great Plains are among the last regions in the United States that have been used as vegetation areas due to drought problems. Using the hybrid varieties of wheat and corn, the area of the Great Plains is cultivated and converted into an agrarian landscape. Today, this region is known for growing wheat, corn and cotton, and a high degree of mechanization of agriculture has greatly increased productivity and simplified works. Three-quarters of US wheat exports are made in eight states of the Great Plains (Kansas, North Dakota, Texas, Montana, Nebraska, Colorado, Oklahoma and South Dakota).

\section{CONCLUSION}

The distinguished and illustrated prairie region of North America basically belongs to the steppes, the zonal type of vegetation taking on this continent enormous spaciousness in the northern temperate latitudes. The Meridian direction and the pronounced openness of the region are the cause of the strong thermal contrasts in it. In the winter half of the year, cold polar air penetrates from the north, and in the summer to the heated land penetrates maritime, subtropical air. This wide openness of the prairie and the mixing of cold and warm air masses, causes very frequent occurrence of destructive winds of the type of tornado. With their devastating effect, they cause great material damage and human casualties in the Great Plains region. In this sense, the climate as a physical-geographical component presents a limiting factor for regional, and above 
all demographic development of the Great Plains. According to Borivoje Ž. Milojević, the lowland regions are in complex interaction with neighboring regions, especially the mountain hinterland. The effects of mountains on the lowlands are more of a physical and geographical nature, while the impacts of the lowlands on the mountains are more anthropogeographical. It is sufficient to mention the local wind, chinook, which comes from the slopes of the Rocky Mountains to the Great Plains. It brings warmer weather, but it can harm the crops, because it causes drought. The occurrence of longer or shorter drought years or periods is a limitation in agricultural production. Today, this problem in the area of the Great Plains is very effectively solved by hydromelioration measures, and the region was transformed into a continuous belt of agricultural surfaces developed on fertile chernozem. Long-term existence of the sea in these areas left rich deposits of lignite, oil and natural gas, on which the development of the secondary sector of the economy is based. In general, the former huge and monotonous prehistoric areas of North America, due to the anthropogenic influences, have in time significantly changed their physiognomy and turned into cultivated regions of the agrarian type.

\section{REFERENCES}

Vasović, M. (1971): Regionalna geografija. Karakteristične regije na Zemljinoj površini. Univerzitet u Beogradu, BIGZ, Beograd.

Đurić, R., Petrović, R. (1965): Ekonomska regionalna geografija sveta III, Zavod za izdavanje udžbenika Socijalističke Republike Srbije, Beograd.

Lješević, A. M. (2010): Geografija zemljišta. Univerzitet Crne Gore. Institut za geografiju Filozofskog fakulteta, Nikšić.

Milosavljević, M. (1990): Klimatologija. Naučna knjiga, Beograd.

Petrović., R. Ilić, J. (1979): Regionalna ekonomska geografija Amerike, Naučna knjiga, Beograd.

Šegota, T., Filipčić, A. (1996): Klimatologija za geografe. Školska knjiga, Zagreb.

https://www.britannica.com/place/Great-Plains

https://www.census.gov/prod/2009pubs/p25-1137.pdf

http://kids.britannica.com/kids/assembly/view/178836

https://www.nps.gov/parkhistory/online_books/geology/publications/bul/1493/images/

fig6.jpg

https://pubs.usgs.gov/bul/1493/report.pdf

https://en.climate-data.org/location/1554/

https://en.wikipedia.org/wiki/Wichita,_Kansas\#cite_note-67

https://weatherspark.com/y/8281/Average-Weather-in-Wichita-Kansas-United-States-

Year-Round

https://www.britannica.com/place/Saskatchewan 